\title{
SCIRPETUM RADICANTIS HEJNÝ IN HEJNÝ ET HUSÁK 1978 em. ZAHLH. 1979, A PLANT ASSOCIATION NEW TO POLAND
}

\author{
KRZYSZTOF SPAŁEK, ARKADIUSZ NOWAK \\ Division of Botany, Department of Biosystematics, University of Opole \\ Oleska 22, 45-052 Opole, Poland \\ e-mail: kspalek@uni.opole.pl \\ e-mail: anowak@uni.opole.pl
}

(Received: March 20, 2003. Accepted: September 11, 2003)

\begin{abstract}
The paper presents a rush community new to Poland - Scirpetum radicantis Hejný in Hejný et Husák 1978 em. Zahlh. 1979, belonging to the Phragmition alliance. It was discovered in fishponds near Olesno in Silesia (SW Poland). The floristic composition and the ecological requirements of this association are presented in the paper. Scirpetum radicantis is considered to be a very rare and endangered plant community in Europe.
\end{abstract}

KEY WORDS: Scirpetum radicantis, Phragmition, distribution, phytosociology, Poland, endangered association.

\section{INTRODUCTION}

Scirpetum radicantis Hejný in Hejný et Husák 1978 em. Zahlh. 1979 was first recognized in the south of the Czech Republic in the littoral zone of fishponds (Hejný, Husák 1978). Subsequently, it was found in Austria (Balátová-Tuláčková et. al. 1993), Germany (Zahlheimer 1979, 1981; Schubert et al. 1995) and in Moravia and the Danube valley in Slovakia (Sucha 1992; Ot'ahel'ová 1995). This association occupies clayey and sandy soils in mesotrophic fishponds, usually abundant in peat sediments in the littoral (Hejný, Husák 1978). In Germany it was recorded from fertile and muddy river banks of the Odra and old Danube riverbeds (Zahlheimer 1979, 1981; Schubert et al. 1995). In Slovakia Scirpetum radicantis is reported from standing waters or periodically inundated areas with clayey basement (Ot'ahel'ová 2001). Scirpetum radicantis is a pioneer heliophyte plant association developing in old riverbeds and oxbow lakes. According to Zahlhmeier (1979) it apparently belongs to rush communities from order Phragmitetalia. From the water side it is contiguous mostly to the Potametea assemblages and from the terrestrial side it borders Phragmition and Magnocaricion associations (Ot'ahel'ová 2001). Occasionally it forms a mosaic of communities with Saggitario-Sparganietum, Eleocharitetum acicularis or Typhetum latifoliae (Ot'ahel'ová 1995). Scirpetum radicantis needs shallow water habitats falling regularly dry (Zahlheimer 1979). It often occurs ephemerally during hot summer periods with the low water level. The community requires wet grounds and tolerates waving of water (Ot'ahel'ová 2001). The characteristic and dominant species for Scirpetum radicantis is Scirpus radicans. Differential species for these associations are: Alisma plantagoaquatica and Eleocharis palustris (Hejný, Husák 1978; Balátová-Tuláčková et. al. 1993). The association is considered to be poor in species and consists of about 3-8 taxa on an average (Zahlheimer 1979; Ot'ahel'ová 1995). Species like Rorippa amphibia, Polygonum hydropiper and Rumex maritimus (Ot'ahel'ová 1995) attain a higher constancy index. This rush plant community is recognized as endangered at both regional and Central European scale (Balátová-Tuláčková et. al. 1993; Schubert et al. 1995; Rennwald 2000; Ot'ahel'ová 2001; Zahlheimer unpubl. data).

This paper describes the Scirpetum radicantis community. A phytosociological table is given and the floristic composition and ecological requirements are discussed.

\section{METHODS}

The fieldwork was conducted during vegetation seasons 2000 and 2001. Scirpetum radicantis community was studied following the Zurich-Montpellier School of Phytosociology (Braun-Blanquet 1964). The phytosociological nomenclature and syntaxonomical attachment are based on Matuszkiewicz (2001). Species names are given according to Mirek et al. (2002). Chlorion concentration was assessed using Mohr's method according to the Polish State Standard PN-75/C-04617. Electrolytic conduction was measured with 


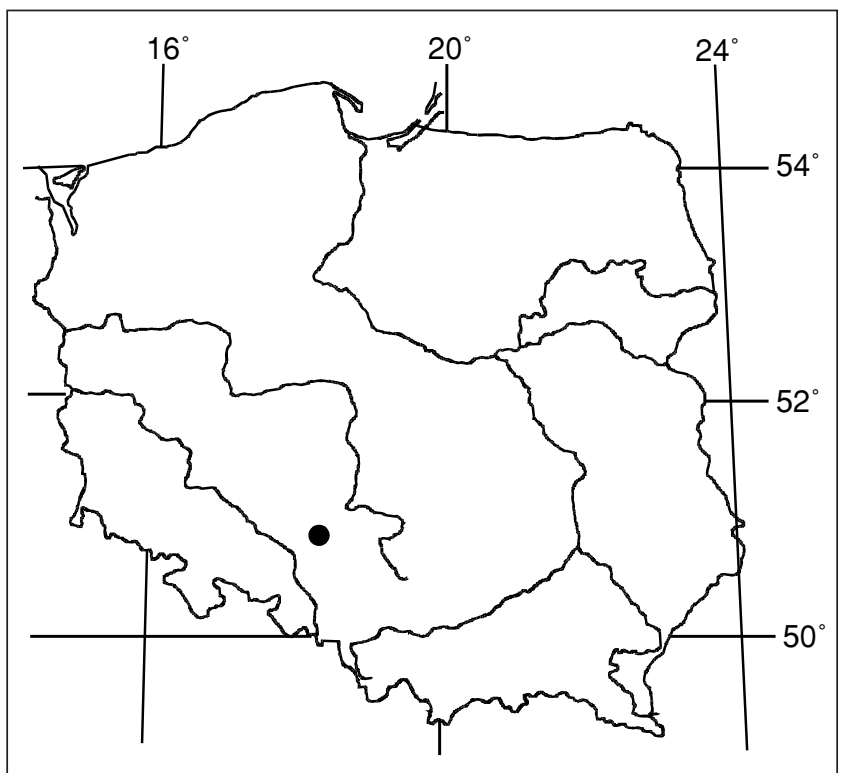

Fig. 1. Locality of Scirpetum radicantis in Poland.

TABLE 1. The physico-chemical characteristics of the pond water.

\begin{tabular}{|c|c|c|c|c|c|c|c|c|c|}
\hline $\begin{array}{c}\mathrm{Cl} \\
{[\mathrm{mg} / \mathrm{l}]}\end{array}$ & $\begin{array}{c}\text { Electrolityc } \\
\text { conductivity } \\
{\left[\mu \mathrm{S} / \mathrm{cm}^{2}\right]}\end{array}$ & $\begin{array}{c}\mathrm{pH} \\
\mathrm{H}_{2} \mathrm{O}\end{array}$ & $\begin{array}{c}\mathrm{BOD}_{5} \\
{\left[\mathrm{mgO}_{2} / \mathrm{l}\right]}\end{array}$ & $\begin{array}{c}\mathrm{O}_{2} \\
\text { Dissolved } \\
\text { oxygen } \\
{[\mathrm{mg} / \mathrm{l}]}\end{array}$ & $\begin{array}{c}\mathrm{PO}_{4} \\
\text { Phosphates } \\
{[\mathrm{mg} / \mathrm{l}]}\end{array}$ & $\begin{array}{c}\mathrm{Na} \\
{[\mathrm{mg} / \mathrm{l}]}\end{array}$ & $\begin{array}{c}\text { Nitrate } \\
\text { nitrogen } \\
{[\mathrm{mg} / \mathrm{l}]}\end{array}$ & $\begin{array}{c}\text { Ammonium } \\
\text { nitrogen } \\
{[\mathrm{mg} / \mathrm{l}]}\end{array}$ & $\begin{array}{c}\text { Nitrite } \\
\text { nitrogen } \\
{[\mathrm{mg} / \mathrm{l}]}\end{array}$ \\
\hline 35 & 370 & 6.9 & 1.55 & 12.8 & 0.04 & 4.05 & 0.15 & 0.19 & 0.010 \\
\hline
\end{tabular}

TABLE 2. Scirpetum radicantis Hejný in Hejný et Husák 1978 em. Zahlh. 1979.

\begin{tabular}{|c|c|c|c|c|c|c|c|c|c|c|c|}
\hline Relevé number & 1 & 2 & 3 & 4 & 5 & 6 & 7 & 8 & 9 & 10 & $\mathrm{C}$ \\
\hline Date: year & 2000 & 2000 & 2000 & 2000 & 2000 & 2001 & 2001 & 2001 & 2001 & 2001 & \\
\hline month & 06 & 07 & 07 & 07 & 07 & 07 & 07 & 07 & 07 & 07 & \\
\hline day & 15 & 06 & 06 & 06 & 06 & 21 & 21 & 21 & 21 & 21 & \\
\hline Cover of herb layer [\%] & 85 & 90 & 85 & 80 & 80 & 85 & 90 & 90 & 85 & 90 & \\
\hline Cover of moss layer [\%] & - & - & - & - & - & - & - & - & - & + & \\
\hline Area of relevé [m²] & 100 & 100 & 100 & 100 & 150 & 100 & 100 & 100 & 100 & 100 & \\
\hline Number of species in relevé & 7 & 8 & 5 & 6 & 8 & 5 & 6 & 9 & 6 & 11 & \\
\hline
\end{tabular}

Ch. \& D.* Scirpetum radicantis

Scirpus radicans

Alisma plantago-aquatica*

$\begin{array}{llll}5 & 5 & 5 \\ + & + & +\end{array}$

the microcomputer conductivitimeter CC-315 and hydrogen ion concentration with Elmetron $\mathrm{pH}$ microcomputer CP-315.

\section{RESULTS}

During floristic investigations carried out in south-western Poland in Olesno District (Silesia), Scirpetum radicantis was found on the bank of a fishpond located northeast from Olesno (Fig. 1). This plant association has not been reported from Poland yet. The total coverage of the community in 2000 was up to 4 ha. Scirpus radicans phytocoenoses developed there in the rush zone adjacent to the open water on muddy, but also sandy soil. The water's depth during the vegetation period was between 10 and $40 \mathrm{~cm}$. According to the literature (Zahlmeier 1979), it could be suspected that during a dry period, i.e. with the low water level, the species composition could change. In such a case, the floristic character of the association as well as its physiognomy may present some similarities to rush associations connected with areas of a changeable water level or even to Isoëto-Nanojuncetea assemblages, especially

\section{Ch. \& D.* Phragmition}

Potamogeton natans* Sparganium erectum

Sagittaria sagittifolia

Myriophyllum verticillatum*

Hydrocharis morsus-ranae*

Nymphaea alba*

Oenanthe aquatica

Nuphar lutea*

\section{Ch. Phragmitetea, Phramitetalia}

Typha latifolia

Phragmites australis

Phalaris arundinacea

Glyceria maxima

Accompanying species

Juncus effusus

\begin{tabular}{|c|c|c|c|c|c|c|c|c|c|c|}
\hline 3 & + & • & • & + & • & + & + & + & + & III \\
\hline 3 & • & • & + & + & + & • & + & • & + & III \\
\hline 3 & + & • & • & $\bullet$ & • & + & + & + & • & II \\
\hline 3 & • & + & • & + & • & • & • & • & + & II \\
\hline 3 & • & • & + & • & • & + & + & • & • & II \\
\hline 3 & • & • & • & + & • & • & + & • & + & II \\
\hline+ & + & • & • & • & • & • & • & • & • & I \\
\hline 3 & • & • & • & • & + & + & • & • & • & I \\
\hline+ & 1 & + & + & + & + & + & + & • & + & $\mathrm{V}$ \\
\hline • & + & • & • & $\bullet$ & • & • & + & 1 & + & II \\
\hline+ & • & • & • & • & • & • & • & + & • & I \\
\hline • & • & • & • & • & • & • & + & • & + & I \\
\hline+ & • & • & • & + & • & • & • & • & • & I \\
\hline
\end{tabular}

Sporadic species - Phragmitetea, Phragmitetalia: Carex acutiformis + (6); Carex pseudocyperus + (3); Cicuta virosa + (1); Glyceria fluitans + (10); Scutellaria galericulata + (4). Accompanying species: Juncus articulatus + (2); Ricciocarpus natans d + (10), Utricularia vulgaris + (10).

Explanation: $\mathrm{C}$ - constancy 
in its juvenile, expanding stadium. Nevertheless, during the observation period a typical rush community developed, characteristic for shallow waters. There was no evidence of Potametea or Isoëto-Nanojuncetea class species, while the amount of Phragmitetalia order taxons was considerable. Scirpetum radicantis built a micro-mosaic complex with Typhetum latifoliae and Phragmitetum australis associations communities along southern edges of the pond. The physico-chemical characteristics of the pond water are shown in Table 1. Scirpetum radicantis is a community poor in species and mostly one-layer. Only exceptionally it has two-layers with evident Scirpus radicans domination and additional occurrence of Typha latifolia and Alisma plantago-aquatica (Table 2). However, the newly discovered locality is characterised by a higher species richness index in comparison to communities described until present. The average species number in the relevé equals 7 . There is apparently no Rorrippa amphibia or any other species subdomination. Rorippa amphibia occurs within the Opole region (SW Poland), almost exclusively on river banks, in oxbow lakes and abundantly in inundation backwater zones of large dam reservoirs. It has been observed in fishponds only occasionally. Similarly as in the location in the Czech Republic (Hejný, Husák 1978), in the study area in 2000 only not flowering individuals were observed. In 2001, the population consisted of both flowering and not flowering plants.

The new locality of Scirpetum radicantis deserves special protection. The local conservation strategy of Olesno commune mentions, that the fishponds should be protected as a Nature-Landscape Complex - a special form of nature conservation based on the Polish Nature Conservation Act.

During the fieldwork, basic threats to plant communities of the ponds were identified. The most harmful seems to be the restoration of the productive surface of fishponds as a consequence of the program of production intensification. As a result, deteriorating use of ponds is implemented, including regular mowing of the rush zone and frequent deepening of pond.

The complete phytosociological and habitat characteristic as well as the present distribution of Scirpetum radicantis in Poland should be a subject to further botanical investigations.

\section{SYSTEMATICAL POSITION OF THE COMMUNITY}

Class: Phragmitetea R. Tx. et Prsg 1942

Order: Phragmitetalia Koch 1926

Alliance: Phragmition Koch 1926

Association: Scirpetum radicantis Hejný in Hejný et Husák 1978 em. Zahlh. 1979

\section{ACKNOWLEDGEMENTS}

We wish to thank Dr Willy Zahlheimer, Dr Wolfgang Ahlmer and Prof. Marica Zaliberova for cooperation and rendering unpublished data. We especially thank Prof. Maria Zając and Prof. Adam Zając for valuable discussions and Dr Adam Stebel for determination of moss taxa.

\section{LITERATURE CITED}

BALÁTOVÁ-TULÁČKOVÁ E., MUCINA L., ELLMAUER T. WALLNÖFER S. 1993. Phragmiti-Magnocaricetea. In: Grabherr G., Mucina L. (eds). Die Pflanzengesellschaften Österreichs. Teil II. Natürliche waldfreie Vegetation. G. Fischer Verlag, Jena-Stuttgart-New York, pp. 79-130.

BRAUN-BLANQUET J. 1964. Pflanzensoziologie, Grźndzźge der Vegetationskunde. Dritte Auflage. Springer Verlag, Wien-New York.

HEJNÝ S., HUSÁK Š. 1978. Higher plant communities. In: Dykyjová D., Květ J. (eds). Pond littoral ecosystems. Springer Verlag, Berlin-Heidelberg-New York, pp. 23-64, 93-95.

MATUSZKIEWICZ W. 2001. Przewodnik do oznaczania zbiorowiska roślinnych Polski. Wydawnictwo Naukowe PWN, Warszawa.

MIREK Z., PIĘKOŚ-MIRKOWA H., ZAJĄC A., ZAJĄC M. 2002. Flowering plants and pteridophytes of Poland. A checklist. Biodiversity of Poland 1: 9-442.

OT'AHEL'OVÁ H. 1995. K výskutu asociácie Scirpetum radicantis Hejný in Hejný et Husák 1978 na Slovensku. Bull. Slov. Bot. Spol. 17: 123-125 (in Slovakian).

OT'AHEL'OVÁ H. 2001. Oenanthetalia. In: Valachovič M. (ed.). Rastlinné společenstvá Slovenska. 3. Vegetácia mokradlí. Academic Electronic Press, Bratislava, pp. 148-160 (in Slovakian).

RENNWALD E. (ed.) 2000. Verzeichnis und Rote Liste der Pflanzengesellschaften Deutschlands. Schr.-R.f. Vegetationskunde 35: 1-800.

SCHUBERT R., HILBIG W., KLOTZ S. 1995. Bestimmungsbuch der Pflanzengesellschaften Mittel- und Nordostdetschlands. G. Fischer Verlag, Jena-Stuttgart.

SUCHA J. 1992. Vodná a močarna vegetácia Kl'účovského ramena Dunaja. (unpublished work), Bratislava (in Slovakian).

ZAHLHEIMER W. 1979. Vegetationsstudien in den Donauauen zwischen Regensburg und Straubing als Grundlage für den Naturschutz. Hoppea, Denkschr. Regensb. Bot. Ges. 38: 3-398 .

ZAHLHEIMER W. 1981. Vegetationskundliche Untersuchung und Kartierung für den Altlaufbogen und die davon eingeschlossenen Flächen im potentiellen Naturschutzgebiet „Gmünder Au”. (unpublished work). 


\section{SCIRPETUM RADICANTIS \\ HEJNÝ IN HEJNÝ ET HUSÁK 1978 em. ZAHLH. 1979, NOWE ZBIOROWISKO ROŚLINNE DLA POLSKI}

\section{STRESZCZENIE}

Artykuł opisuje nowe dla Polski zbiorowisko szuwarowe - zespół sitowia korzenioczepnego Scirpetum radicantis Hejný in Hejný et Husák 1978 em. Zahlh. 1979, należące do związku Phragmition. Zespół ten został stwierdzony w stawach hodowlanych koło Olesna na Śląsku w południowo-zachodniej Polsce. Przedstawiono jego skład florystyczny i warunki ekologiczne. Scirpetum radicantis jest zbiorowiskiem bardzo rzadkim i ginącym w Europie.

SŁOWA KLUCZOWE: Scirpetum radicantis, Phragmition, rozmieszczenie, fitosocjologia, Polska, zespół zagrożony. 